\title{
UNCERTAIN LABOUR
}

\author{
Migrant workers in \\ karbi anglong, assam
}

BY MICHAEL HENEISE 

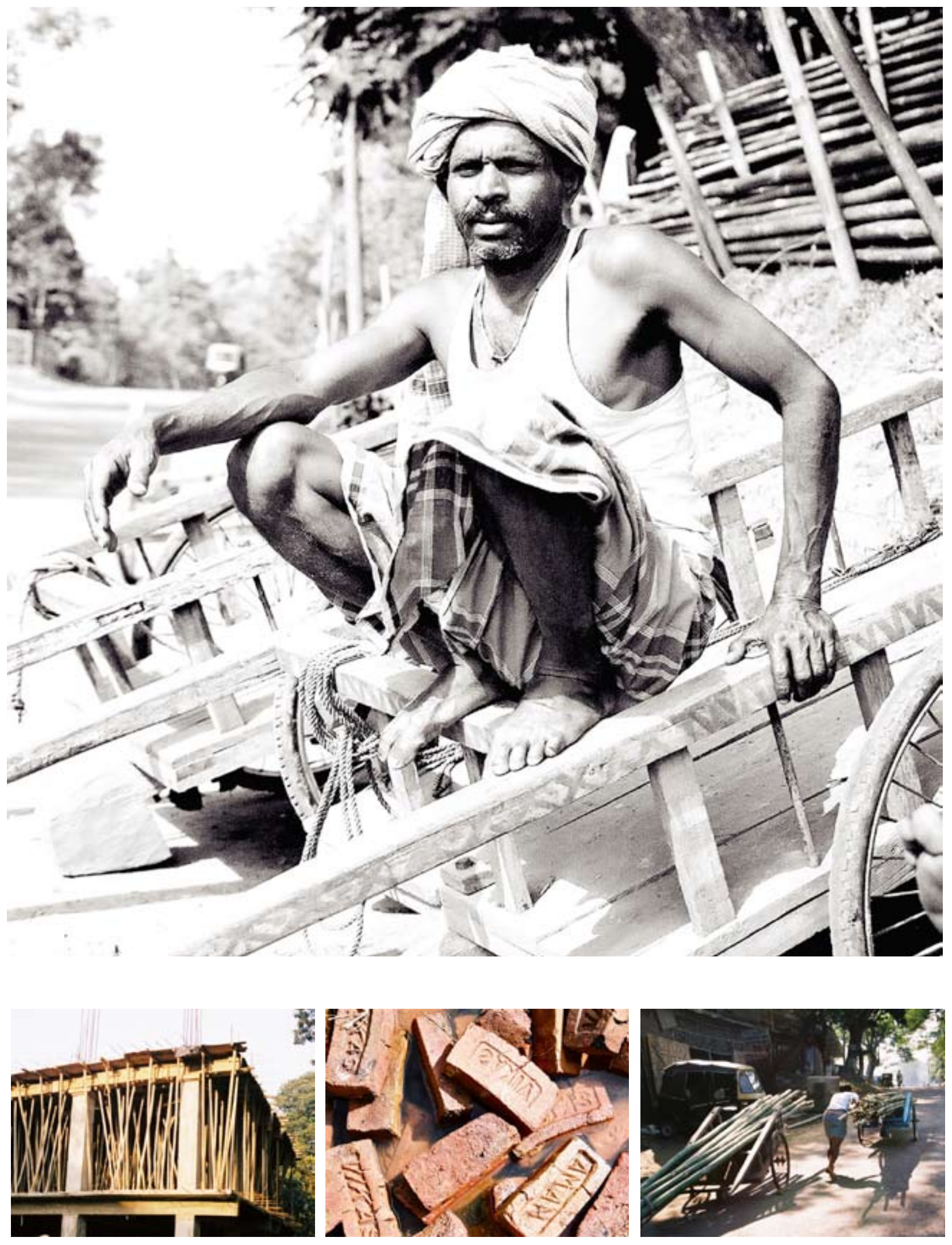

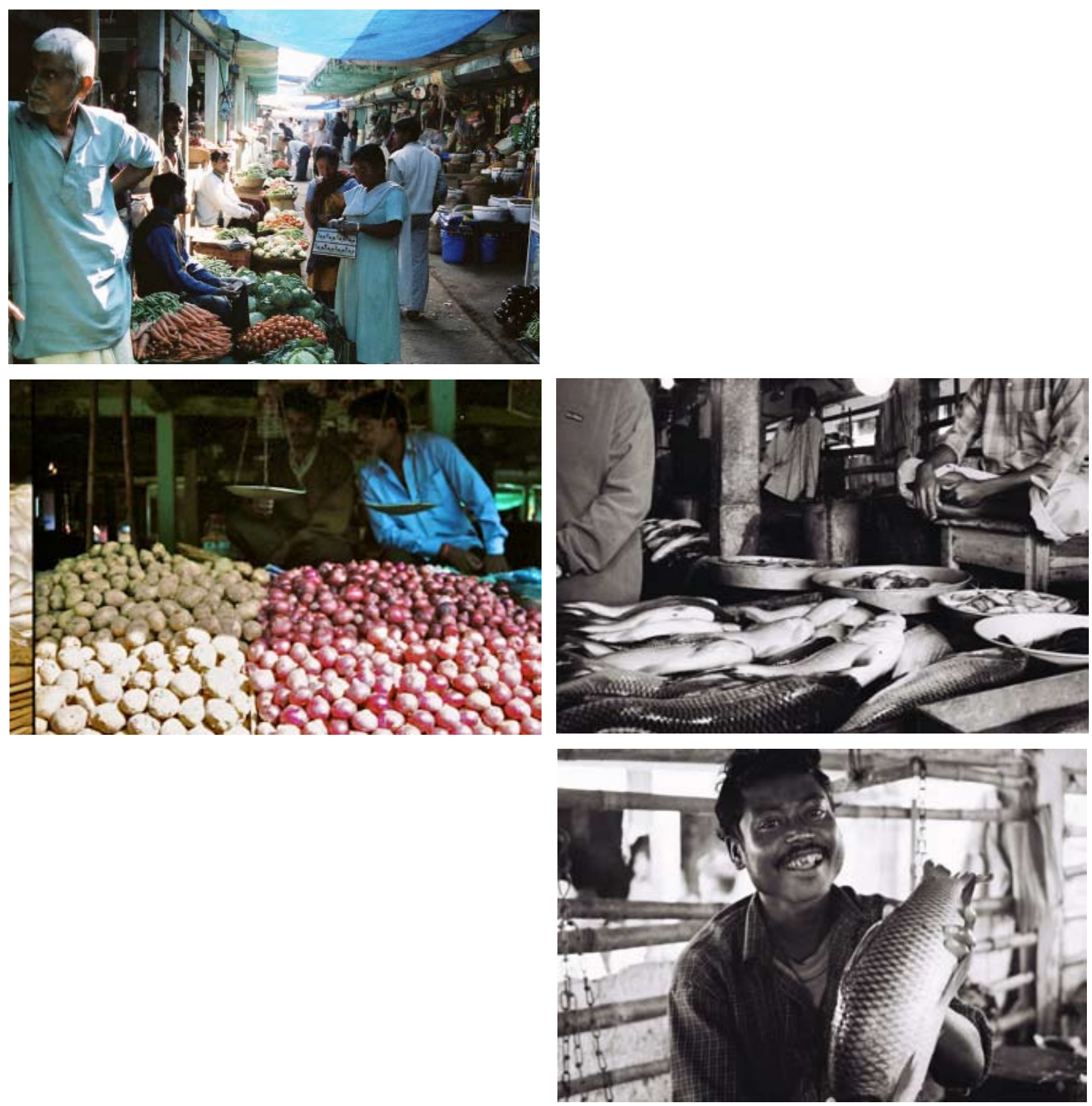
$\mathrm{D}$ iphu, Karbi Anglong, December, 2005. As I walk down the road with my old Nikon SLR camera in-hand, a middle-aged Bihari migrant worker summons me and then waits patiently on his thela gari as I search my pockets for a spare roll of Ilford XP2 film. Communication is limited - managed through a series of hand gestures, some limited Hindi, and laughter. But I surmise that his main objective is the supply and transport of heavy bamboo to building sites where it is employed in scaffolding and in the setting of concrete in multi-level home construction. Like bamboo, red brick is readily available and produced locally - mostly by workers from Bihar. Small plots are leased from local Karbi landowners, kilns are built, and their surnames are proudly baked into each end product.

Though situated deep in the jungles of Eastern Assam, Diphu is linked by railway to Guwahati, and thus to the rest of India. The Jan Shatabdi Express only stops for two minutes in Diphu. Getting off is a matter of timing and aiming precision. Following the sound of squealing brakes, dozens of passengers shove to the exit as the train slows to a halt. Holding one's luggage firmly in one hand, one must aim for a small wooden platform using the luggage as a counter-balance - or plummet nearly six feet into red clay.

Since its inauguration in 1970 as the district seat, Diphu has grown from a large village to a proper city of nearly 60,000 . Most of the construction related with this growth has been in the hands of Bangladeshi migrant workers skilled in masonry, carpentry, plumbing and electrical work.

In order to get a sense of how connected Diphu is to other regions, I entered the local market place. Though much of what is available can be produced locally, vegetables grown cheaply elsewhere are easily shipped in and sold for a profit. To my surprise, the ample supply of silver carp on sale was shipped in from Andhra Pradesh! Local fisheries, I am told, are seasonal and insufficient to meet demand. (Continued on page 47) 

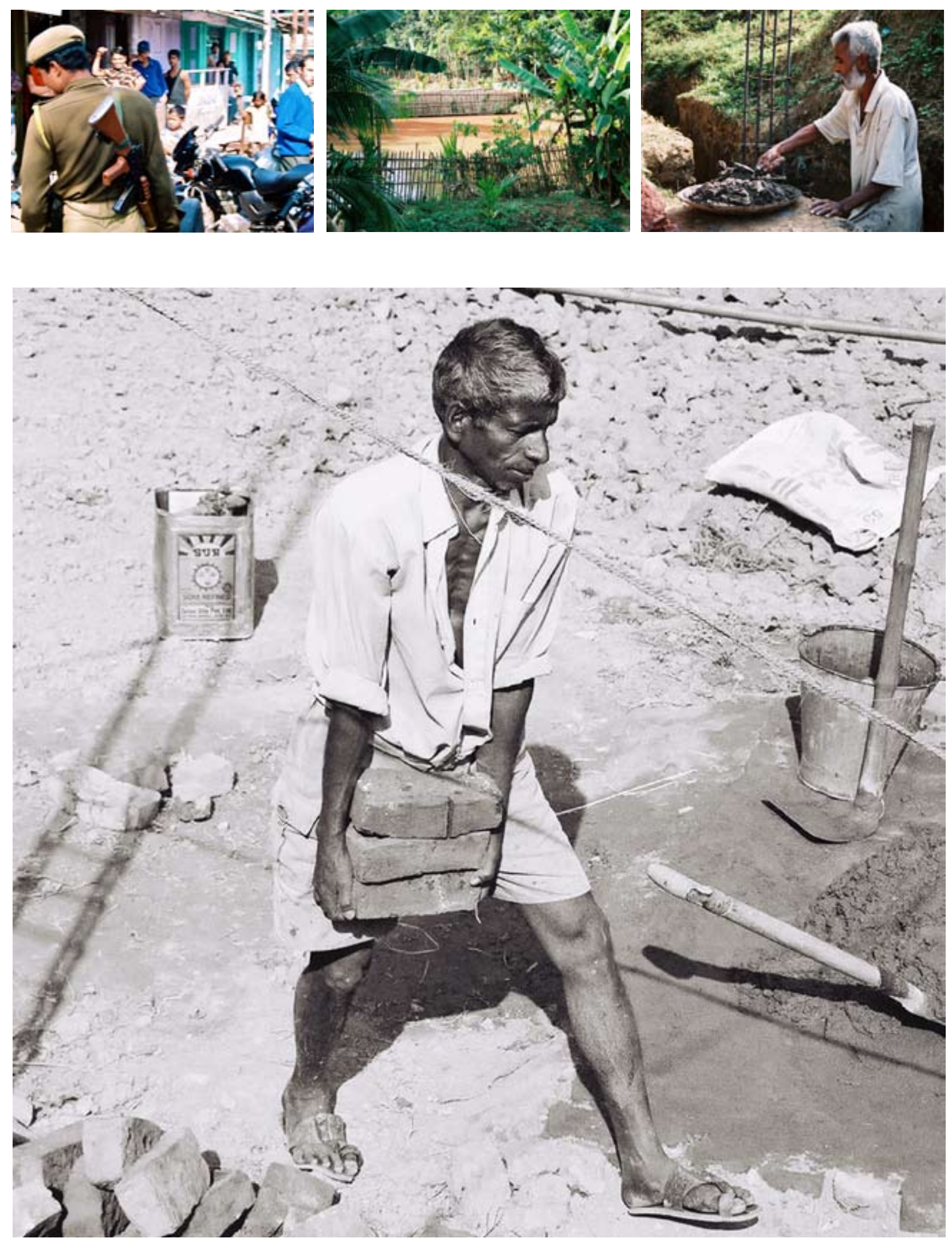
The cheerful exchanges I had with construction material transporters, shop owners, barbers, carpenters, and Bollywood video-disc sellers that day belied the unease and anxiety one could sense beneath the surface of genuine cordiality. Two months before I arrived, the underground militant groups Dima Halom Daoga (DHD) and United Democratic People's Solidarity (UDPS) had engaged in a series of tit-for-tat attacks and counter-attacks against villages of the opposing ethnic group. The DHD on behalf of the Dimasas, and UDPS on behalf of the Karbis had been responsible for ninety-one deaths, dozens of burned down villages, and over forty thousand refugees. Though the Indian Army's involvement was unclear, I could sense the general unease at their presence in and around Diphu.

Xenophobia, racial prejudice and violence against migrant workers - particularly Biharis - had also been a growing problem in Karbi Anglong over the past five years or so. The killing of Bihari workers at the hands of the United Liberation Front of Asom (ULFA), in particular, had become an expected news item in the daily papers and on local radio stations. The recent violence between the DHD and UDPS created a deep sense of unease and uncertainty for the migrant workers. Their ability to work was contingent upon peaceful relations with local patrons and customers. When tensions ran high, 'scapegoat' was an unenviable position to be in.

Despite the lack of security, sluggish economic growth and lack of work opportunities in their places of origin - Bihar, West Bengal or Bangladesh - have dissuaded many migrant workers from returning. There is also a great deal of hope that state and central government-sponsored development projects would materialize giving a boost to the construction and services industry.

As my short two-week stay in Diphu came to a close, I stuffed the side-pockets of my cargo pants with cartridges of black and white film, and braced myself for the moving Jan Shatabdi Express to Guwahati. Diphu disappeared from view in an instant, though the images and voices of those I met still remain fresh in my mind. Indeed migrant workers in this hidden jungle-city wrestle day-to-day with isolation, uncertainty, and sometimes violence. But they will likely stay and continue to stamp their names into the bricks of small edifices, and brave the Northeast monsoon. 迠 